Jurnal Ilmu Dan Teknologi Kesehatan

Vol 7, No 2, Maret 2020,

ISSN: 2338-9095 (Print)

ISSN: 2338-9109 (online)

\title{
Evaluation of Midwifery Care Standard Policy BPJS Health Participants
}

\author{
Astri Nurdiana, Ella Nurlailasari \\ Faculty of health science Unsika \\ Email: astri.nurdiana@fikes.unsika.ac.id
}

\author{
Article history \\ Posted, Jan 13th, 2020 \\ Reviewed, Feb 25th, 2020 \\ Received, March 10th, 2020
}

\begin{abstract}
Enforcement of national health insurance organized through Badan Penyelenggara Jaminan Kesehatan (BPJS) experiences various polemics, one of which relates to financing for midwifery care listed in Permenkes No. 52 of 2016 concerning health service fare standards in the health insurance program, whether the standard rate can cover the needs of services provided by midwives in rural or urban areas or not. The result found that there is no difference in midwifery care fare between urban and rural areas $(p>0.05)$, but there are differences in midwifery care fare between rural and BPJS fare standard $(p<0.05)$ and between urban fare and BPJS fare standard $(p<0.05)$
\end{abstract}

Keywords: evaluation; BPJS; midwifery care; standard rate

\begin{abstract}
ABSTRAK
Pemberlakuan jaminan kesehatan nasional yang diselenggarakan melalui Badan Penyelenggara Jaminan Sosial mengalami berbagai polemik salah satunya berkaitan dengan pembiayaan pada penyedia pelayanan asuhan kebidanan yang tercantum pada Permenkes No 52 tahun 2016 tentang standar tarif pelayanan kesehatan dalam program jaminan kesehatan, apakah standarisai tarif tersebut dapat menutup kebutuhan palayanan yang diberikan oleh bidan baik di pedesaan ataupun diperkotaan atau tidak. Ditemukan hasil bahwa tidak terdapat perbedaan tarif asuhan kebidanan antara di perkotaan dan pedesaan $(p>0,05)$, namun terdapat perbedaan tarif asuhan kebidanan antara tarif di pedesaan dan tarif BPJS $(\mathrm{p}<0,05)$ serta antara tarif di perkotaan dan tarif BPJS $(\mathrm{p}<0,05)$.
\end{abstract}

Kata kunci: evaluasi; asuhan kebidanan; BPJS; tarif standar 


\section{INTRODUCTION}

A healthy and prosperous life is one of the 17 Sustainable Development Goals (SDG), SDG is implemented with universal principles, integration and inclusive to ensure that no one is left behind or No-one left behind (Bapennas, 2017). Equitable and equitable health services are the hope of all Indonesian people, Schröders et al. (2017) in their study stated that injustice in health services between rural and urban communities was real in Indonesia, which caused not all rural communities to obtain optimal services such as the community who live in urban areas (Schröders et al., 2017).

The Government of Indonesia is continuously making efforts to equalize health services. This is realized by the existence of government policies with the implementation of national health insurance. Health BPJS is a transformation of PT. Askes, the transformation took place from November 2011 to 31 December 2013, so PT Askes was officially declared disbanded and continued with the implementation of the Health BPJS, which was carried out since January 1, 2014 (BPJS Health, 2017). BPJS Health has the public authority stipulated in the Law, which is to hold the interests of national social security based on the principles of humanity, benefits, and social justice for all Indonesian people. Also, BPJS health is given the authority to do general binding rules and duty to manage public funds ( Health BPJS, 2017).

In its realization, BPJS Health found many conflicts in the community, one of which was a conflict related to health service providers, the Pikiran Rakyat newspaper said that until now BPJS Health had harmed around 2400 BPJS Health partner hospitals. In line with this online media, CNN noted that at the beginning of its implementation BPJS Health had experienced a budget deficit of Rp. 3.3 trillion, increasing to Rp.5.7 trillion in 2015, Rp. 9.7 trillion in 2016, Rp. 9.75 trillion in 2017 and Rp. 10.98 trillion in 2018 (Gumelar, 2018).

The enactment of the national health insurance $(\mathrm{JKN})$ organized through the BPJS is one of the government's efforts to implement the millennium development target, which then continues to be the target of sustainable development at this time. BPJS health is a means for the community to get fair and equitable health services, which are expected to increase public access to health services without financial constraints, geographical location, and limited services. JKN can 
reach all groups wherever and whenever, people can get health services both in government and private agencies (BPJS Health, 2017) On the journey of JKN implementation by BPJS experienced various polemics, quoted from Seftiawan (2018) that INACBGs must be replaced, their application is not suitable in Indonesia, health services are paid based on the classification of disease diagnoses. Disease financing based on INACBGs causes much cheaper funding, so the utilization of health care facilities for patients has not been maximized (Seftiawan, 2018). This study aims to evaluate the BPJS Health midwifery care tariff policy based on Permenkes No. 52 of 2016 concerning JKN tariff standards. The benefit of this research is to evaluate the implementation of BPJS Health midwifery participant tariffs conducted by midwives in Karawang Regency and the identification of midwifery care rates based on rural and urban areas in Karawang Regency.

\section{METHOD}

This study is a comparative analytic study comparing the rate of 2 unpaired groups, namely the non-BPJS Health rates in urban and rural areas, which are then compared to the standards rate set by the Health BPJS. Data collection was carried out through a direct survey of midwives who were used as research respondents. The study population was all midwives in 50 working areas in Karawang Regency, as many as 864 , and samples were midwives who were used as research respondents with a total of 31 research subjects in 50 work areas in the Regency. Karawang. Sampling through purposive sampling was selected by midwives who networked with BPJS Health in rural areas and midwives in urban areas. The 50 work areas are classified as rural areas if they do not meet the criteria for urban area classification based on the head of the Central Statistics Agency No. 37 of 2010, so that 50 working area health centers in Karawang Regency consist of 20 rural areas and 30 urban areas.

The inclusion criteria in this study were midwives who had independent practice and provided midwifery services for both JKN participants and non JKN participants, the exclusion criteria for this study were if the midwife filled out the research questionnaire with unclear or one of the questions about the tariff was not filled. Analysis of research data is an unpaired comparative analysis using the Kruskal-Wallis test, post hoc test using Mann-Whitney. 


\section{RESULTS AND DISCUSSION}

Overview of Research Locations

Karawang is the Java Sea borders one of the provinces in West Java with an area of $1,753.27 \mathrm{~km} 2$, a regency that is rich in agriculture and industry, in the north, the Karawang regency, southeast is bordered by Purwakarta regency, east is bordered by Subang regency, south is bordered by with Bogor and Cianjur Regencies, and the west was bordering Bekasi District. Karawang consists of 30 districts and 297 villages and 12 villages. The total population in Karawang Regency is 2,316,489 inhabitants, with 1,129,215 inhabitants of the female population and $1,187,274$ inhabitants of the male population. Karawang Regency has 21 Hospitals, 50 community health center, 65 community health center assistants, 2,301 Posyandu, 324 clinics, 123 pharmacies, and 51 polines spread throughout the Karawang Regency in 2017. There are 2151 nurses, 1450 midwives, 33 dental nurses, 59 nutritionists, and 325 pharmaceutical power. Karawang has 370 specialist doctors, 300 general practitioners, and 92 dentists. Karawang has two public universities and one health college. There were 46 cases of maternal deaths with the highest cause of death caused by preeclampsia, bleeding, and heart disease. In this study, data collection was carried out on the independent midwife practice $(\mathrm{PMB})$ in rural and urban areas in Karawang regency, data obtained were 36 midwives in rural areas and 38 midwives in urban areas, the categorization of rural and urban areas was made based on the head of the Central Statistics Agency No. 37 of 2010 (Statistics, 2018).

\section{The Role of Midwives in the JKN Era}

In this JKN era, midwives contributed to providing midwifery care as a whole and evenly because midwives could network with first-level health service facilities to be able to service BPJS participants. So in addition to regulating health service tariffs at the first level and referral level, the Health BPJS also regulates pregnancy, childbirth, postpartum and newborn service rates by midwives, as stated in Permenkes No. 52 of 2016 concerning health service tariff standards in the program health insurance with details of service rates as follows (Indonesia, 2016):

1. ANC examination, according to the standard, is given in the form of a package of at least four times the inspection of Rp. 200,000, if the ANC examination is not carried out in one place, the inspection is paid Rp.50,000

2. Normal vaginal deliveries performed by midwives are paid Rp. 700,000 
3. PNC examination according to the standard carried out as much as two times the visit of the first postpartum and neonates, one visit postpartum and the third neonate of Rp.25,000 per visit.

Health insurance financing is very crucial to determine the quality of health services provided, and health insurance financing must be both sides of the health service system, namely health workers as service providers and patients as service recipients. Not only in Indonesia, but justice in health financing is also a growing issue in a country with high population growth, India. Health system financing has an impact on the financial problems faced by health service providers. Study results published in a journal entitled "Who pays for healthcare in Bangladesh? An analysis of progressivity in health system financing" found that the payment of health costs paid to health workers is far below the consumption standard of the primary needs of people in India, it is measured based on three variables, namely food consumption financing, consumption financing other than food and health service financing (Molla \& Chi, 2017).

\section{Pregnancy Care Rates}

Based on the results of the study in table 3 about the costs paid by patients to midwives for pregnancy services both in rural and urban areas have the same average rate. Statistical test results in table 3 show that there are no differences in ANC rates in urban and rural areas and between rural and BPJS rates ( $p>0.05)$, but there are differences in ANC rates between urban rates and BPJS rates $(\mathrm{p}$ $<0.05)$.

Table 1. Comparison of Pregnancy Care between Rural Areas, Urban and BPJS Rates

\begin{tabular}{lclc}
\hline \multicolumn{1}{c}{ Pregnancy Care Rates } & n & \multicolumn{1}{c}{ Median (min-max) } & P-value \\
\hline Rural areas & 36 & $50 \mathrm{k}(30 \mathrm{k}-110 \mathrm{k})$ & 0.011 \\
Urban areas & 38 & $50 \mathrm{k}(30 \mathrm{k}-125 \mathrm{k})$ & \\
BPJS & 37 & $50 \mathrm{k}(50 \mathrm{k}-50 \mathrm{k})$ &
\end{tabular}

Post hoc Mann-Whitney test: rural vs urban $(\mathrm{p}=0,054)$, rural vs BPJS $(\mathrm{p}=0,783)$, urban vs BPJS $(\mathrm{p}=0,002)$

Based on the results of the study in table 1 about the costs paid by patients to midwives for pregnancy services both in rural and urban areas have the same average rate. Still, there are differences in ANC rates between rates in urban areas 
and BPJS rates. The lowest price of pregnancy care by midwives in both rural and urban areas in Kabupaten Karawang is Rp.30,000 while the highest rate in rural areas is 110,000 and in urban areas is 125,000 , the services provided by midwives at each pregnancy check-up consist of history, physical examination, provision of blood-added vitamins (Fe) and TT immunization if needed, while the standard rate paid by the BPJS for reimbursing the cost of a pregnancy visit is 50,000 for each visit, the amount of the rate can be sufficient or very can also be very less than the normal standard rate of midwives which is applied to patients.

The difference in rates is due to urban communities in Karawang regency having a much higher income compared to rural communities, based on Statistics data (2018) Karawang Regency is known that the economical turnover of people in urban areas is higher than in rural areas, this is evidenced by the data that $33.13 \%$ of the Karawang people work in the field of trade, $29.92 \%$ in the industrial sector and only $14.18 \%$ work in the field of agriculture (Statistics, 2018).

Incomes in urban areas affect the rates set by BPM, and rural communities are still heavily influenced by socio-cultural influences, which occurred in Karawang regency. Some people still choose to check themselves in traditional birth attendants who are considered cheaper than checking in midwives. Also, BPM in urban areas are strategically located and easily accessible to patients, so that the strategic location can be a selling point for midwives to set higher service rates compared to in rural areas, this is in line with Werdhani's research (2019) which said that environmental aspects are things that can affect one's health condition, rural and urban conditions in access to health are significantly different, even one of which can cause maternal or infant deaths caused by low access and socio-cultural problems in the community (Werdhani, 2019).

Similar to pregnancy care rates, there are no significant differences in delivery rates in rural and urban delivery, the statistical test results in table 4 show that there are no differences in delivery rates in urban and rural areas ( $p>0.05)$. Still, there are differences in labor rates between rural rates and BPJS $(\mathrm{p}<0.05)$ and between urban rates and BPJS rates ( $\mathrm{p}<0.05$ ). 


\section{Childbirth Care Rates}

Table 2. Comparison Childbirth Care rates between Rural Areas, Urban and BPJS

\begin{tabular}{lclc}
\hline \multicolumn{1}{c}{ Childbirth Care rates } & n & \multicolumn{1}{c}{ Median (min-max) } & P-value \\
\hline Rural areas & 36 & $1.100 \mathrm{k}(700 \mathrm{k}-2.000 \mathrm{k})$ & 0.0001 \\
Urban areas & 38 & $1.250 \mathrm{k}(800 \mathrm{k}-2.500 \mathrm{k})$ & \\
BPJS & 37 & $700 \mathrm{k}(700 \mathrm{k}-700 \mathrm{k})$ &
\end{tabular}

Post hoc Mann-Whitney test: rural vs urban $(\mathrm{p}=0,0382)$, rural vs BPJS $(\mathrm{p}=0,0001)$, urban vs BPJS $(\mathrm{p}=0,0001)$

Likewise, the statistical test results in table 2 show that there were no differences in labor rates accompanied by complications in urban and rural areas ( $\mathrm{p}>0.05)$. Still, there were differences in labor rates accompanied by complications between rates in rural areas and BPJS ( $\mathrm{p}<0.05)$ and between childbirth care rates with urban complications and BPJS rates $(p<0.05)$. Similar to pregnancy care rates, there are no significant differences in delivery rates in rural and urban delivery. Still, there are differences in labor rates between rural and BPJS rates and between urban and BPJS rates, as well as the statistical test results in table 2 it was found that there were no differences in delivery rates accompanied by complications in urban and rural areas. Still, there were differences in delivery rates accompanied by complications between rates in rural areas and BPJS, as well as between rates of delivery care with urban complications and BPJS rates. In this case, complications that are managed by midwives are severe complications that must be treated as an emergency treatment to prevent maternal death, such as in labor and bleeding conditions that require immediate treatment.

Table 3. Comparison of Childbirth Care with Complications rates between Rural, Urban and BPJS

\begin{tabular}{lcll}
\hline $\begin{array}{c}\text { Childbirth Care with } \\
\text { Complications rates }\end{array}$ & n & \multicolumn{1}{c}{ Median (min-max) } & P-value \\
\hline Rural areas & 36 & $1.550 \mathrm{k}(700 \mathrm{k}-3.500 \mathrm{k})$ & 0.0001 \\
Urban areas & 38 & $1.825 \mathrm{k}(900 \mathrm{k}-3.000 \mathrm{k})$ & \\
BPJS & 37 & $950 \mathrm{k}(950 \mathrm{k}-950 \mathrm{k})$ & \\
\hline
\end{tabular}

Post hoc Mann-Whitney test: rural vs urban $(0,815)$, rural vs BPJS $(\mathrm{p}=0,0001)$, urban vs BPJS $(\mathrm{p}=0,0001)$ 
Statistical test results in table 3 show that there is no difference in postpartum care rates in urban and rural areas $(\mathrm{p}>0.05)$. Still, there are differences in postpartum care rates between rates in rural areas and BPJS ( $p$ 0.05) and between rates in urban areas and BPJS rates $(\mathrm{p}<0.05)$. The median normal delivery rate for rural delivery is Rp. $1,100,000$, - while for the city is Rp. 1,250,000, while the median value for labor rates with rural complications is Rp. 1,550,000 and in the city Rp. 1,825,000. The standard setting for childbirth care fees issued by the BPJS Health is very far below the median value in rural and urban rates of Rp.700,000 for normal delivery and Rp.950,000 for delivery with complications.

The impact of funding that is far below the standard is the elimination of food supply facilities for JKN participants. This is a solution for both parties, both midwives and patients, to implement justice aspects in health financing. It is necessary to further study on this matter because the reduction in quality standards of services provided by midwives to JKN patients should be something that should not happen. Still, midwives are in a position as service providers and as entrepreneurs who cannot rule out economic aspects in their business trips. Marhenta, Satibi, and Wiedyaningsih (2018), in their study of the quality of BPJS services in the first-level health facilities in Karanganyar District, showed that the financing and health services provided significantly influenced the level of patient satisfaction.

Funding in health service is crucial for midwives because midwives are professionals who have the right to provide health services during pregnancy, childbirth, BBL, and KB. Until now. Midwives are the third-highest number of health workers after general practitioners and nurses in Karawang Regency (Karawang, 2019). Midwives are required to provide quality health services, the provision of quality services must be supported by the availability of adequate facilities and infrastructure in midwife practice facilities, because this is a health worker is one element influencing the knowledge and changes in patient behavior (Espich, 2007).

It is undeniable the implementation of JKN in Indonesia can overcome the problem of access to health workers during childbirth for people with middle to lower economic conditions, the results of a study conducted by Brooks et al. (2017) in Indonesia regarding birth by health workers to the 
poor obtained results that the community The poor who are JKN participants are more likely to be able to deliver in health care facilities and deliver by professional health workers compared to the poor who are not JKN participants (Brooks et al., 2017). There are $1,028,526$ pregnant women in West Java, and $18.97 \%$ of them have complications, pregnant women who experience these complications are likely to have complications during childbirth. Therefore health funding for patients accompanied by birth complications is very much needed following health conditions in Indonesia (Depok Health Service, 2016).

Looking at the conditions of delivery care rates in tables 4 and 5 which rates of delivery care issued by BPJS Health are still far below the median delivery rates in rural and urban delivery should the Indonesian government pay more serious attention because this is related to high rates maternal and neonatal deaths that still occur in Indonesia, in 2019 there were $306 / 100,000$ maternal deaths and 14 / 1,000 infant deaths in Indonesia, a decrease in the quality standard of services provided by midwives is not impossible to contribute to the occurrence of maternal or infant mortality, even though This needs to be studied further. (Kementerian Kesehatan Republik Indonesia, 2019).

\section{Rates for Postpartum Care and Newborns}

Table 4. Comparison of postpartum Care Rates between Rural, Urban and BPJS

\begin{tabular}{lclc}
\hline Postpartum Care Rates & n & \multicolumn{1}{c}{ Median (min-max) } & P-value \\
\hline Rural areas & 36 & $50 \mathrm{k}(0-200 \mathrm{k})$ & 0.0001 \\
Urban areas & 38 & $50 \mathrm{k}(0-300 \mathrm{k})$ & \\
BPJS & 37 & $25 \mathrm{k}(25 \mathrm{k}-25 \mathrm{k})$ &
\end{tabular}

Post hoc Mann-Whitney test: rural vs urban $(0,465)$, rural vs BPJS $(\mathrm{p}=0,0001)$, urban vs BPJS ( $\mathrm{p}=0,0001)$

Table 5. Comparison of Newborn Care rates between Rural, Urban and BPJS

\begin{tabular}{lclc}
\hline \multicolumn{1}{c}{ Newborn Care rates } & n & \multicolumn{1}{c}{ Median (min-max) } & P-value \\
\hline Rural areas & 36 & $50 \mathrm{k}(0-200 \mathrm{k})$ & 0.0001 \\
Urban areas & 38 & $50 \mathrm{k}(0-300 \mathrm{k})$ & \\
BPJS & 37 & $25 \mathrm{k}(25 \mathrm{k}-25 \mathrm{k})$ &
\end{tabular}

Post hoc Mann-Whitney test: rural vs urban $(0,616)$, rural vs BPJS $(\mathrm{p}=0,0001)$, urban vs BPJS (p=0,0001) 
Statistical test results in table 4 show that there is no difference in postpartum care rates in urban and rural areas. Still, there are differences in postpartum care rates between rural and BPJS rates and between urban rates and BPJS rates. Similar to postpartum care rates, the statistical test results for newborn care in table 5 show that there are no differences in the rates of newborn care in urban and rural areas. Still, there are differences in the rates of newborn care between rates in rural areas and BPJS and between urban rates and BPJS rates.

The post-delivery care rates in some midwives do not impose service rates for their patients because the delivery of midwifery, postpartum and newborn midwifery services into one service package, so that after birth the patient will receive ongoing services for mothers and post-delivery infants by midwives who conduct labor assistance, not only physical examination of the mother and baby provided by the midwife, but the midwife also performs a variety of additional services such as bathing the baby and baby care until the baby's umbilical cord is detached but based on the results of the study it cannot be done on patient patients JKN because the standard rate set by the Health BPJS for midwives is far below the standard imposed by the PMB, which is
Rp.25,000, - for one childbirth visit and Rp.25,000, - for one newborn visit, but some midwives still apply it will but not make an additional payment from the patient or in other words is done voluntarily.

This is following research conducted by Erim, Kolapo, and Resch (2012) that the fulfillment of facilities and infrastructure in a health service place is essential because it is a manifestation of the sense of responsibility of health workers to the community, it is also an aspect of supporting the sustainability of health services (Erim et al., 2012). Kruk et al., (2016) conducted a study on the availability of neonatal emergency facilities in health services written in his journal entitled Obstetric Facility Quality and Newborn Mortality in Malawi: A Cross-Sectional Study, in the journal, mentioned that the quality was not aware of from a place of health care is associated with an increased risk of infant death in Malawi (Kruk et al., 2016). In line with the results of the study, Lee, Madhavan, and Bauhoff (2016) wrote in their journal about Levels and Variations in Quality of Facilities-Based Antenatal Care in Kenya: Evidence from the 2010 Service Provision Assessment that facilities in health services play an important role in 
terms of efficiency and patient acceptance of the health services provided. (Lee et al., 2016).

Vesel et al. (2013) conducted a study in Ghana on health service assessments and found that there were still $33 \%$ of low birth weight babies born in health care facilities with inadequate facilities, this had an impact on the difficulty of conducting resuscitation in infants. Kruk et al. (2016) in their research on maternal service facilities in Africa found that $40 \%$ of childbirth facilities are in poor condition, in line with this study that the midwife's independent practice as a place of health care that provides services for pregnancy, childbirth until the newborn does not yet have facilities and equipment are $100 \%$ fulfilled. In contrast, health care facilities that provide maternal and neonatal services fulfillment of facilities, infrastructure, and medicines are absolute, one of the lowest is the unavailability of resuscitation equipment for newborns. It is time to fund BPJS health in Indonesia for the welfare of patients and health workers who provide services, currently sourced from participant contributions, but on the results of research conducted by Ahsan (2017) which was also published by BPJS Health in 2017 that BPJS Health has an opportunity to increase funding from cigarette taxes. In contrast to
Indonesia, if you see the reality in Nigeria that health insurance funding comes from the government budget, additional payments by patients, state taxes, donations from donor countries, health insurance from private parties, community-based health insurance that is voluntary and health insurance private sector (Uzochukwu et al., 2015).

\section{CONCLUSION}

The cost of midwifery services determined by BPJS Health both during pregnancy, childbirth, childbirth, and newborns is still far below the median value of the standard rates in urban and rural areas, midwives as health workers need to work hard to be able to provide optimal services with suboptimal funding. BPJS funding for health in Indonesia is time to be improved for the welfare of patients and health workers who provide services.

\section{REFERENCE}

Ahsan, A. 2017. Ringkasan Riset JKN-KIS. Jakarta.

Bapennas. 2017. Sustainable Development Goals. Retrieved February 28, 2019, from http://sdgs.bappenas.go.id

BPJS Kesehatan. 2017. Seputar BPJS Kesehatan. Retrieved March 1, 2019, from https://bpjskesehatan.go.id/bpjs/dmdocuments/eac 4e7a830f58b4ade926754f74b6caf.pdf

Brooks, M. I., Thabrany, H., Fox, M. P., 
Wirtz, V. J., Feeley, F. G., \& Sabin, L. L., 2017. Health facility and skilled birth deliveries among poor women with Jamkesmas health insurance in Indonesia: a mixed-methods study. BMC Health Services Research. https://doi.org/10.1186/s12913-0172028-3

Dinas Kesehatan Depok. 2016. Profil Kesehatan Dinas Kesehatan Provinsi Jawa Barat 2016. Research.

Erim, D. O., Kolapo, U. M., \& Resch, S. C. 2012. A rapid assessment of the availability and use of obstetric care in Nigerian healthcare facilities. PLoS ONE.

https://doi.org/10.1371/journal.pone.00 39555

Espich, J. E. 2007. Applying bloom's taxonomy of educational objectives. National Society of Programmed Instruction.

https://doi.org/10.1002/pfi.4180030906

Gumelar, G. 2018. Pangkal "Penyakit" Defisit BPJS Kesehatan. CNN Indonesia, pp. 1-6.

Indonesia, M. K. R. 2016. Standar Tarif Pelayanan Kesehatan dalam Penyelenggaraan Program Jaminan Kesehatan (2016). Indonesia.

Karawang, D. K. 2019. Profil Kesehatan Kabupaten Karawang. Karawang: Dinas Kesehatan Kabupaten Karawang.

Kementerian Kesehatan Republik Indonesia. 2019. Kesehatan Indonesia Menghadapi Revolusi Industri 4.0. Jakarta.

Kruk, M. E., Leslie, H. H., Verguet, S., Mbaruku, G. M., Adanu, R. M. K., \& Langer, A. 2016. Quality of basic maternal care functions in health facilities of five African countries: an analysis of national health system surveys. The Lancet Global Health. https://doi.org/10.1016/S2214-
109X(16)30180-2

Lee, E., Madhavan, S., \& Bauhoff, S. 2016. Levels and variations in the quality of facility-based antenatal care in Kenya: Evidence from the 2010 service provision assessment. Health Policy and Planning, 31(6), 777-784. https://doi.org/10.1093/heapol/czv132

Leslie, H. H., Fink, G., Nsona, H., \& Kruk, M. E. 2016. Obstetric Facility Quality and Newborn Mortality in Malawi: A Cross-Sectional Study. PLoS Medicine, 13(10).

https://doi.org/10.1371/journal.pmed.1 002151

Marhenta, Y. B., Satibi, \& Wiedyaningsih, C. 2018. Pengaruh TIngkat Kualitas Pelayanan BPJS dan Karakteristik Pasien Terhadap Kepuasan Pasien di Fasilitas Kesehatan Tingkat Pertama. Journal of Management and Pharmacy Practice, 8(1), 18-23.

Molla, A. A., \& Chi, C. 2017. Who pays for healthcare in Bangladesh? An analysis of progressivity in health systems financing. International Journal for Equity in Health. https://doi.org/10.1186/s12939-0170654-3

Schröders, J., Wall, S., Hakimi, M., Dewi, F. S. T., Weinehall, L., Nichter, M., $\mathrm{Ng}, \mathrm{N} .2017$. How is Indonesia coping with its epidemic of chronic noncommunicable diseases? A systematic review with meta-analysis. PLOS ONE. https://doi.org/10.1371/journal.pone.01 79186

Seftiawan, D. 2018. Kenapa BPJS Kesehatan Defisit Triliunan Rupiah? Ini alasannya. Pikiran Rakyat, pp. 1-3. Retrieved from https://www.pikiranrakyat.com/nasional/2018/11/09/kenap a-bpjs-kesehatan-defisit-triliunanrupiah-ini-penjelasannya-432979

Statistik, B. P. 2018. Karawang Regency in 
Figures. Karawang: Badan Pusat Statistik.

Uzochukwu, B. S. C., Ughasoro, M. D., Etiaba, E., Okwuosa, C., Envuladu, E., \& Onwujekwe, O. E. 2015. Health care financing in Nigeria: Implications for achieving universal health coverage. Nigerian Journal of Clinical Practice. https://doi.org/10.4103/11193077.154196

Vesel, L., Manu, A., Lohela, T. J., Gabrysch, S., Okyere, E., Ten Asbroek, A. H. A., Kirkwood, B. R.
2013. Quality of newborn care: A health facility assessment in rural Ghana using survey, vignette and surveillance data. BMJ Open. https://doi.org/10.1136/bmjopen-2012002326

Werdhani, R. A. 2019. Medical problem in Asia pacific and ways to solve it: The roles of primary care/family physician (Indonesia Xperience). Journal of Family Medicine and Primary Care, 8(5), 1523-1527. 